\title{
IBSE IN CHEMISTRY EDUCATION - TESTING STUDENTS' SKILLS AND TEACHER TRAINING
}

\author{
Hana Čtrnáctová, Lenka Čtrnáctová, Petr Šmejkal \\ Charles University in Prague, Faculty of Science, Albertov 6, Prague 2, Czech Republic
}

\begin{abstract}
Inquiry Based Science Education (IBSE) as a new kind of education has been introduced into both the individual countries and the $\mathrm{EU}$ as a whole as an appropriate method for improvement on the current unsatisfying state of science education. Recently, new curriculum documents started to take effect in Czech Republic; these documents emphasize acquiring key competences and support the implementation of new strategies of teaching and learning. Many suggestions for IBSE education were also created as a part of national and international projects. For this reason, our article will focus mainly on the preparedness of pupils/students and their teachers for this new teaching method as a further condition of the application of IBSE into schools. In the first part of the article, we will list methods, procedures and results of a research that aimed to determine whether the pupils/students have enough skills to use the inquiry based method of teaching. In the second part of the article, we will start by focusing on the determination of teacher preparedness for IBSE and then on the preparation and realization of the IBSE training system for in-service and pre-service teachers in Czech Republic. This training system is based on the identification of a scientific "mystery" and active work of the teachers connected with their experience of inquiry and discovery. In the third part of the article, we will talk about the TEMI project which creates training programs for science teachers using IBSE and in which our country participates right now.
\end{abstract}

\section{Introduction}

At the beginning of the $21^{\text {st }}$ century, Czech Republic came to similar conclusions as the rest of the EU - students' scientific knowledge, including chemistry, was very formal and shorttermed, often based on memorization and without any deeper understanding and the ability to apply the knowledge in practice.

IBSE as a new approach to education seemed to be an appropriate method for the improvement of the current state (Franklin, 2000) (ESTABLISH, 2010) (Banchi, H., Bell, R., 2008). However, there are at least four basic conditions that have to be satisfied in order to use IBSE in a country. It is clear that the current curricular documents must make space for this type of education, and there must also be good and appropriate topics in the subjects themselves; the students must be able to accept this type of education, and, last but not least, the teachers must be able to teach in this way.

Since 2005, Czech Republic has had new curricular documents that put emphasis on the acquisition of key competences, and thus support the implementation of new strategies of teaching which involve pupils more and support their own activity. Topics for IBSE education have started to be created as a part of national and international projects. For this reason, we are going to focus on the remaining two conditions for applying IBSE in education: the readiness of students and the readiness of teachers for the use of a new teaching method. 


\section{IMPLEMENTING INNOVATIONS IN A NON-FORMAL STUDENT LABORATORY CONTEXT}

The students' ability to use inquiry-based education was the subject of the national GAČR (Czech Science Foundation) project that aimed, among other things, to determine whether our students have the necessary component skills for this type of education - asking scientific question, suggesting hypotheses, designing and performing experiments, working with schemes, tables and graphs, reaching conclusions, etc. One of the methods we used was solving a group of problems in a didactic test verifying these skills in chemistry on students of primary and secondary schools in 2011-2012. The results showed that our students are fairly well prepared for the IBSE method (Čtrnáctová \& al., 2013).

As for the teachers, one part of our national project research was a questionnaire survey performed in the same time period. The survey was trying to find out whether the teachers have already encountered the IBSE method and whether they consider it suitable for chemistry teaching at our schools. As for the teachers, a questionnaire inquiry done at the same time had also as its goal to determine whether the teachers have encountered the IBSE method and whether they consider it appropriate for chemistry teaching at our schools. The questionnaire inquiry among teachers was performed as a part of the European project ESTABLISH in which we participated and it had similar results. For these reasons, we consider the main problem of the application of the IBSE method in Czech Republic the insufficient preparation of the teachers for its teaching. To solve this problem, we started to organize a training system for in-service and pre-service teachers as a part of the European project TEMI (see below) and as a follow-up to the results of the project ESTABLISH and the national project "Making Science Is Easy".

\section{IBSE - The Current Method for Active Teaching and Learning of Science}

The international comparative studies in science education performed at the turn of the century showed that the interest of young people in studying science had dropped considerably. Students of secondary schools in most European and other countries are also fairly uninterested in science education, and the subject of chemistry is actually one of the long-term least favourite subjects at these schools. The way science is taught at schools is rightly considered one of the main causes of the decreasing interest (Abd-El-Khalick, 2005). Experts from the field of didactics try to right this situation as a part of both national and international projects whose goal is to analyse the current national initiatives in the given area and gain elements of know-how from their representative cross-section; these elements could initiate a profound change in the area of young people's interest in the study of science and they could be transferable and usable in the educational systems of other states (European Commision, 2007). IBSE is of a special interest since, according to what was found so far, it proved its efficiency in the secondary education by both increasing the students' interest and improving their results; it also aroused the motivation of teachers (Sherwood, 2007). It is also listed as an important fact that IBSE is not contrary to the traditional pedagogical approaches, which can - and should - be combined in the teaching of science in 
order to adjust the education to different styles of student thinking and their age preferences (European Commision, 2007).

The change in general approach to education reflects the fast increase of new knowledge in science; the development of information and communication technologies; a change of objective needs and perspectives in the development of society and new demands for practical applications. IBSE is an educational protocol based on students' own investigations with use of many activating methods.

Czech Ministry of Education, Youth, and Sports (MŠMT) also took a stance on IBSE; it listed the advantages and problems of this approach from the point of view of our educational system in its report (MŠMT, 2009). The advantages of IBSE adjusted according to the MŠMT in 2009 are: students learn active problem solving in teams, students' interest in science increases, students acquire scientific methodology (like collection and comparison of data, use of IT and the Internet etc.) and students are much better prepared for their further life and lifelong education, both through the method of work and through the durability of acquired knowledge. The problems with IBSE adjusted according to MŠMT, 2009 are: teachers are worried about the realization of experiment-based work in their own classes and they also fear the unknown, teachers lack training in "active" teaching (they are more used to lecturing, especially at secondary schools), teachers' superiors are not always sufficiently convinced in reality of the usefulness and effectiveness of this type of teaching and the teachers are worried whether the students have sufficient skills to make use of this new type of teaching.

IBSE is a process of diagnosing a problem, experimenting, recognition of alternatives, planning the research, determination and verification of hypotheses, searching for information, creation of models, discussion with peers and argumentation (Čtrnáctová \& Č́žková, 2010). The inquiry type of teaching gives students a chance to work with various materials and tools, to rely on their previous knowledge, to improve their grasp of scientific methods and to see their strong and weak points. Another important point of inquiry is that it gives the students experience with creating questions, and gathering and analysing evidence (Pellegrino J. W., Histon M. L., 2012). When the inquiry ends, the student should be able to create his own opinion about the processes and methods used in science (Apedoe \& Reeves, 2006) (Franklin, 2000). National Science Education Standards (NSES), published by the National Council for Research in 1996, are, among others, concerned with the way scientists perform their research - the inquiry cycle which can have various forms (ESTABLISH, 2010). One example is the cycle shown in Fig. 1.

\subsection{IBSE - The Learning Cycle}

The learning cycle can be used to create the structure of IBSE education since it is one of the most common and most effective models for the realization of teaching and learning. 


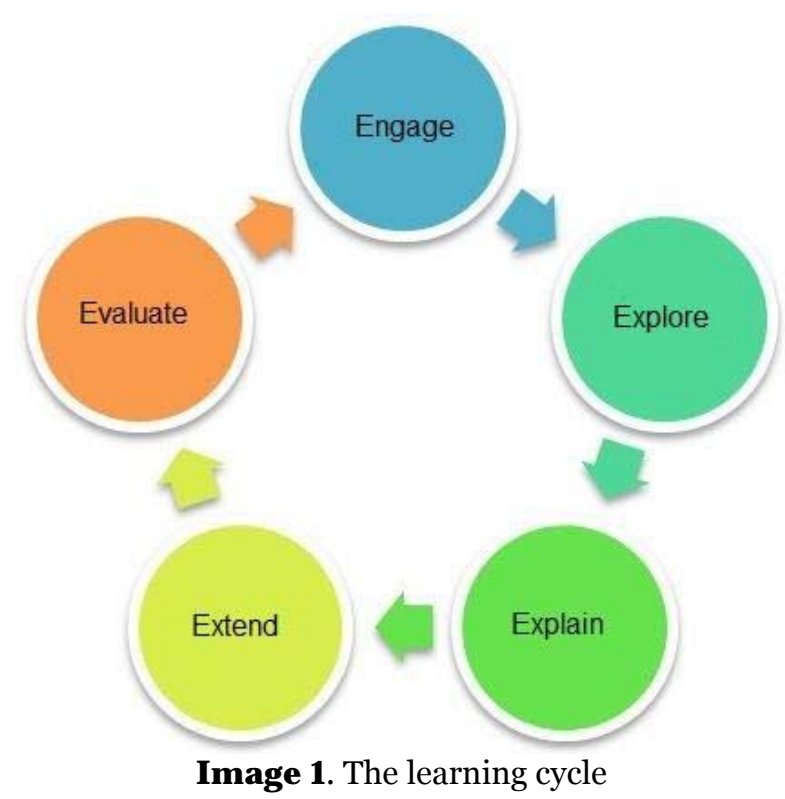

- Engagement - in this stage it is necessary to arouse interest and curiosity about the given topic; the teacher has a chance to activate learning, to evaluate previous knowledge and to give the students a chance to make use of their previous knowledge about the given topic.

- Exploration - this is a good stage for involving students in the inquiry, letting them to ask questions and develop hypotheses regarding their work without the teacher's direct commands. The students start to gather data and information and to suggest and perform observations and experiments.

- Explanation - the use of methods leading to processing data and evidence by individual groups and class as a whole; discussion and explanation of scientific terms connected to the investigation through whole-class lecturing.

- Extension - the teacher helps to strengthen the acquired knowledge by extending the evidence to new situations.

- Evaluation - the teacher asks questions of higher order that help the students with judging, analysing and evaluating their work.

\section{IBSE and Students' Skills - Research and Results Achieved}

In our research, we started by focusing on the determination and hierarchy of required students' scientific knowledge at various degrees of secondary schools, as follows from the set teaching cycle. We have created a structure of knowledge necessary in order to realize IBSE in the school practice. Adequate science subject tasks were created for the various types of knowledge - though we will focus on the subject of chemistry - and assembled into tests given to the students in the appropriate age category, i.e. at the end of low secondary schools and in upper secondary schools. These tasks included finding out which city has the best water for a aquarium (from a table of $\mathrm{pH}$ values), comparing graph and table to find out what concentration of $\mathrm{CO}_{2}$ is in said water, finding questions to already-filled-in answers etc. 
Therefore, we have selected testing and its statistical evaluation as the main method of our research in this phase of project solving (Čtrnáctová \& al., 2013). Testing was focused on five basic skills at all education levels: asking science-related questions, acquiring information from various sources (text, tables, graphs, schemes, pictures, etc.), arranging the results achieved, evaluating these results, and forming the conclusions.

The research was a part of a project of The Czech Science Foundation with cooperation between Charles University in Prague (Faculty of Science) and Masaryk University in Brno (Pedagogical faculty) which took place between 2010 and 2013 and was called Students' skills in biology, geography and chemistry: research into planned, realized and achieved curriculum in implementation phase of the curricular reform. With this project, we were able to collect our data from the didactics test for students and the questionnaires for teachers.

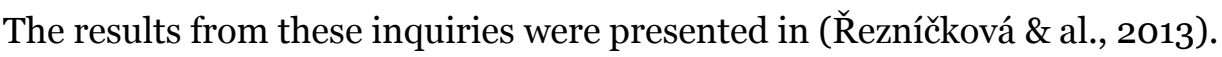

\subsection{Project: Students' Skills in Science}

The main goal of this project supported by The Czech Science Foundation was to propose an interlinked system of student skills based on their multi-level analysis. These are skills that should be acquired in science at the end of lower secondary school and at the end of upper secondary school (grammar school) in order to be able to work using the IBSE method. Partial goals of the project were: students' skills in chemistry - a proposal of a subject skill system at primary/secondary level, analysis of teachers' opinions about the suggested skill system, testing students' skills at lower and upper secondary level and teacher interviews about student skills.

Following from the mentioned teaching cycle, we created a skill structure necessary for its realization in school practice. We focused on skills related mainly to the formation of research questions (phase 1 and 2 of the IBSE teaching cycle), searching for information in various sources and their critical evaluation (phase 2 and 3 of the IBSE teaching cycle) and inferring, forming and presenting the conclusions (phase 4 and 5 of the IBSE teaching cycle). The international evaluation PISA, organized by OECD, also shows that our students have problems with these skills (Čtrnáctová, Čižzová, Marvánová, \& Pisková, 2007); (Mandíková, D., Houfková J., 2012).

We have chosen a skill test based on a single complex aquaristics-related problem (see examples of tasks above) as a good tool for finding out the state of the abovementioned skill group; this problem required the students to solve many component problems. The complex problem was outlined as a story with many pitfalls that required use of various skills to overcome. The component problems in the test were focused on the listed basic skills, both general and specific (Bayerová, Cídlová, \& Kuběnová, 2013) (Čćžková \& al., 2009) (Čtrnáctová, Čížková, Hlavová, \& Řezníčková, 2012). Since the ability to perform chemical experiments couldn't be verified directly, we replaced it by skills inseparably connected to the realization of chemical experiments - basics of chemical nomenclature, writing of chemical equations, understanding of chemical equilibrium and chemical calculations. 


\section{IMPLEMENTING INNOVATIONS IN A NON-FORMAL STUDENT LABORATORY CONTEXT}

Therefore, we were tracking not only general skills but also some selected skills specific for the subject of chemistry.

The chemistry skill test had two versions: one for lower secondary school, the other for upper secondary school. Both versions had, as a baseline, seven analogical problems focused on general skills. For the upper secondary school, this baseline was extended by problems requiring some special chemical knowledge (see above).

The individual test problems' focus on the abovementioned skills is specified in Table 1.

Table 1: Specification of skills in chemical test tasks

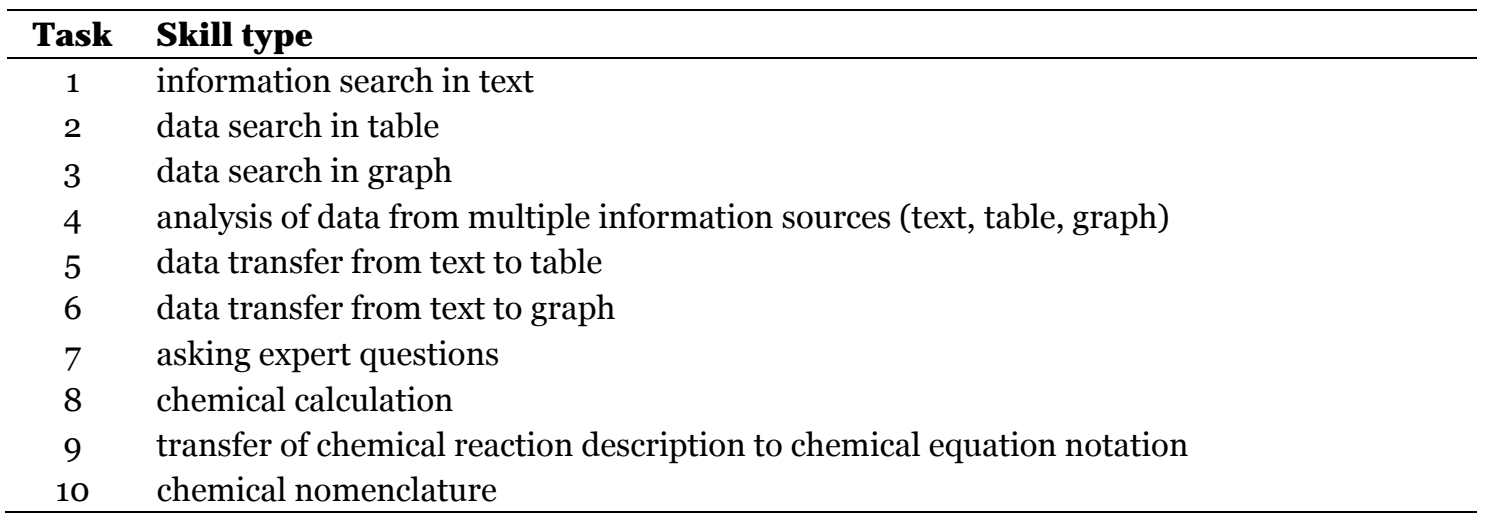

The prepared knowledge test was given in May-June 2012 during chemistry lessons to the total of 684 students (431 from lower secondary schools and 253 from upper secondary schools). The students were not informed of the test beforehand. One part of the test was a 20-item questionnaire. The first item related to the students' opinions about the individual test problems and their difficulty, others were formulated as questions about their approach to chemistry, guessing the success rate in other selected skills similar to the ones in the test and the inclusion of the acquirement of similar skills into chemistry teaching from the students' point of view.

While the students were tested, the teachers at secondary level (118 teachers) and college level (24 teachers) were asked to complete a similar questionnaire containing 6 question groups. The questions in groups 1 to 4 were related to their opinions about the ageappropriateness of the individual problems and to the preliminary guessing of the students' success rate in solving them, the questions in group 5 were related to guessing the students' success rate in other selected skills similar to the ones in the test and the inclusion of the acquirement of similar skills into chemistry teaching from the teacher's point of view. The analysis of their responses reached the conclusion that the respondents in general agree with the suggested skill system for these subject; interesting fact is that the higher the school level, the lower the demands. See Figure 2 for average success rate of students (\%) in various problems of the test. 


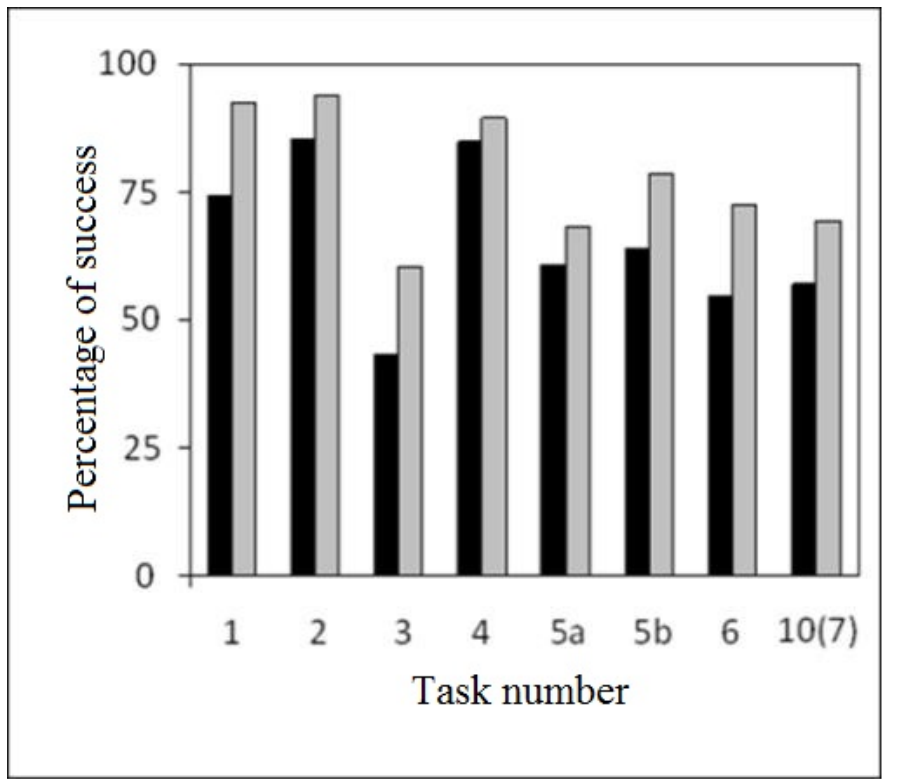

Figure 2. The average success rate in various problems. Black column = lower SE, grey column $=$ higher SE.

The answer to the question "do the students' results in general skills necessary for working with information depend on their age?" can be seen in Table 2. It shows the average success rate of solving individual test problems for younger and older students. It is clear that older students were more successful with all problems focused on the general skills necessary for working with information.

Table 2. Students' success rate

Problem / success rate (\%)

\begin{tabular}{ccccccccccccc}
\hline $\begin{array}{c}\text { Number of } \\
\text { task }\end{array}$ & 1 & 2 & 3 & 4 & $5 \mathrm{a}$ & $5 \mathrm{~b}$ & 6 & 7 & $8 \mathrm{a}$ & $8 \mathrm{~b}$ & 9 & $10(7)$ \\
Lower SE & 74,5 & 85,6 & 43,6 & 85,0 & 60,6 & 64,3 & 54,7 & --- & --- & -- & -- & 56,9 \\
Upper SE & 92,5 & 93,7 & 60,3 & 89,9 & 68,2 & 78,9 & 72,9 & 29,2 & 47,4 & 71,2 & 72,2 & 69,6 \\
\hline
\end{tabular}

Both groups of students were most successful in solving problems related to searching for information in text or a table (problems 1 and 2), and in answering six dichotomist questions in problem 4 where the $50 \%$ chance of guessing the right answer played a significant role (the success rate was in range of 70-90\%). The bigger problems started with tasks that required the students to make their own table, to find data in a graph and to make their own, and to put the gathered information in their own words (problems 3, 5, 6 and 7). The results pertaining to the answer to the third research question - whether the students' results in the area of specific chemical skills differ with the type of school - were interesting and alarming. Actually, the students in both groups had very bad results with the problem requiring some basic chemical calculations (Table 2). 


\section{IMPLEMENTING INNOVATIONS IN A NON-FORMAL STUDENT LABORATORY CONTEXT}

As we have already said, the teachers made preliminary guesses - at the same time as the students were tested - about the students' success rate in solving the individual problems. When the questionnaires and tests were compared, it was found that the students were mostly better in solving the problems than the teachers expected. On the other hand, the students' results in the case of chemical calculations were much worse. The average teacher guess about the success rate of the students of the $3^{\text {rd }}$ year of four-year grammar school was $57 \%$ while the actual success rate was mere $18 \%$; the average teacher guess for the success rate of the students of the $7^{\text {th }}$ year of eight-year grammar school was $74 \%$ while the actual success rate was mere $43 \%$. These students are all the same age, but they attend different types of grammar schools.

The problem in question is not the last one in the test and the success rate for the following problems was significantly higher. This rules out that the possibilities that students wouldn't "reach the problem" or that they would skip it because of "tiredness" at the end of the test. The detailed analysis of the teacher questionnaire results, including the teacher guesses and real success rate of older and younger students in solution of all test problems, is published, among others, in (Čtrnáctová \& al., 2013).

We have interviewed the teachers about the importance of general student skills and their acquirement in science education. 12 chemistry teachers were interviewed in semi-structured interviews. The interview included questions like: How do you understand the term 'student skills', 'Is it possible to teach students to ask chemical questions', 'What is your experience with individual work of students', etc. The analysis of the answers led to the conclusion that the respondents generally lack a clear idea about these skills and the way to train them.

The questionnaire investigating teachers shows that most of the teachers agree with the skill structure demanded by IBSE. The test results show that most of the students have necessary skills for IBSE, at least at a basic level. The teacher interviews show that their ideas about acquiring skills for IBSE are problematic. The results acquired so far show that inquirybased education could be in practice realized even now and students do not have to be specifically prepared for it; however, it is necessary to put more effort into IBSE training for the teachers.

As far as the teachers go, one part of our research as a part of a national project was a questionnaire survey performed at the same time period aiming to find out whether the teachers have encountered the IBSE method and whether they consider it suitable for chemistry teaching at our schools. A total of 142 teachers participated in the questionnaire survey and the results show that the teachers have very little knowledge about this method. The questionnaire survey which was performed as a part of the European ESTABLISH project we participated in had similar results.

\section{Teacher Trainings and the TEMI project}

We believe that the main problem for IBSE application in our country is the insufficient preparation of teachers for this teaching method. For this reason, we became a part of the TEMI project (Teaching Enquiry with Mysteries Incorporated), which started in 2013 and is 
coordinated by Queen Mary University in London. It is a science education project meant for lower and upper secondary schools teachers with the main goal to prepare and carry out teacher trainings focused on IBSE that would lead to a change in the teaching of science and mathematics throughout Europe. TEMI teacher trainings give the teachers new knowledge and skills that will allow them to connect better with their students, access exciting new resources and a vast support necessary in order to incorporate this teaching method into their lessons (Sherborne, T., 2014) (TEMI team, 2015).

Teachers fully experience the whole process in the role of students to get familiar with the TEMI and IBSE method. We mainly want to change directive teaching into enquiry teaching, change the paradigm from knowledge to skills and change the perspective of assessment of students' outcomes. All of these problems are barriers for IBSE teaching in the Czech Republic and elsewhere. Our teacher trainings consist of practical two-day workshops for teachers from the Czech Republic and they use mysterious tasks to create curiosity and motivation.

We use known and new activities and units in our trainings. We work with activities from the ESTABLISH project (Polymers, Chemical Care, Photochemistry etc.), the „Making Science Is Easy“ project (activities for practical work in primary and secondary schools, more than 100 activities from physics, chemistry and biology) and new activities specifically designed for the TEMI project. In our country, we have trained 62 out of the goal of 90 teachers so far.

The introductory part of the workshop is devoted to getting to know the TEMI project and its main aspects. This is followed up by individual tasks, which are presented in such a way that the teachers are in the role of students and try to solve the mystery at hand with the help of our lecturers. About 10 to 12 enquiry tasks are presented during each workshop. The results of solving these tasks are summarized in a short seminar with discussion at the end of the day. An integral part of the workshop is also a show, usually in the form of a "magic performance" full of mysterious experiments.

The participating teachers write out their opinions and views on the program of the training and IBSE in general into questionnaires at the end of each day of the two-day workshop.

Based on these questionnaires, we have found out that $81 \%$ of the participants want to try out the TEMI approach to teaching in class. To the question: "What do you think you have gained from this workshop?" the teachers answered: $65 \%$ gained motivation to innovate their teaching, $63 \%$ got new tools for teaching, $55 \%$ gained a new approach to teaching, $52 \%$ better understood the principles of IBSE and $52 \%$ acquired useful examples of good practice. The teachers' satisfaction in applicability, enjoyment, importance and interest of the workshops ranges between $85-95 \%$. 


\section{Conclusion}

Given the problems in the current way of teaching chemistry in our country and abroad, many interested experts try to search for a way to improve on it. The inquiry-based education method seems to be one of the suitable solutions to this problem. In order for it to be applied in our school practice, we need to master its component skills. For this reason, our research aimed to find out whether the students on the level of lower and upper secondary school possess these skills or not. Apart from that, we also verified selected specific chemical skills.

It was confirmed that the older students had better general skills necessary for the application of the IBSE method, compared to the younger students, and this was true for all corresponding problems in the test. As for the influence of the type of the school, the level of necessary general skills was a bit higher in the students of the $7^{\text {th }}$ year of eight-year grammar school compared to their peers at lower secondary school or in the $3^{\text {rd }}$ year of the four-year grammar school, but this was only statistically significant for some problems.

In the area of selected special chemical skills (chemical calculation, conversion of verbal description of a chemical reaction into a chemical equation, chemical nomenclature, elementary ideas about chemical equilibrium), which were only tracked for the older students, the students of the $7^{\text {th }}$ year of eight-year grammar schools were more successful than the students of the $3^{\text {rd }}$ year of four-year grammar schools in three of the problems; only in the problem related to conversion of verbal description of a chemical reaction into a chemical equation did they have almost the same success rate. Apart from that, and outside of the original focus of the research, we have confirmed that the students' skills in the area of chemical calculations are very low, significantly worse that the guesses of the actual teachers of the tested students.

When we compare the results of students in different test problems and the results the authors of this article got in the past, it supports the thesis that the students' failure when solving some theoretical problems in chemistry is not necessarily caused by the failure to acquire necessary mathematical skills or logical operations; the disconnection between chemistry and everyday life might also play its part. According to the foreign experience (MŠMT, 2009), the teaching of science and technical disciplines, including chemistry, should build on the students' natural interest in what happens around us. Therefore, chemistry should not be taught merely as a "theory far from the everyday life" - on the contrary, the problems should be, when possible, explained in the context of everyday, well-known situations.

The results of our research are being further used in teacher trainings which we are organizing thanks to the TEMI project. We want the enquiry approach to teaching to become a reality in the Czech Republic as much as possible.

Financial support of the $7^{\text {th }}$ FP EU TEMI (No 321403) project is gratefully acknowledged. 


\section{References}

Abd-El-Khalick, F. (2005). Developing deeper understandings of nature of science: the impact of a philosophy of science course on pre-service science teacher's view and instructional planning. International Journal of Science Education, pages 15-42.

Apedoe, S. A., \& Reeves, T. C. (2006). Inquiry-based learning in undergraduate science education. Journal of science education and technology, pages 321-330.

Banchi, H., Bell, R. (2008). The many levels of inquiry. Science and Children, 46(2), pages 26-29.

Bayerová, A., Cídlová, H., \& Kuběnová, G. (2013). Pohled žáků a učitelů na test vybraných žákovských dovedností v chemii. Aktuálne smerovanie výskumov $v$ dizertačných prácach $\mathrm{z}$ didaktiky chémie (stránky 15-25). Bratislava: Univerzita Komenského. ('The view of pupils and teachers on a test on selected student skills in chemistry')

Čížková, V., \& al. (2009). Increasing the Effectiveness of Ecological Education Through Interactive Tasks. Journal of Baltic Science Education, pages 110-119.

Čtrnáctová, H., \& al. (2013). Standards of Selected Chemical Skills of Primary School Pupils and Grammar School Students. Chemické listy, pages 897-905.

Čtrnáctová, H., \& Čížková, V. (2010). Inovace obsahu a metod výuky přírodních věd v současné společnosti. Chemické rozhl'ady, pages 139-146. ('Innovation of the content and methods of science education in today's society')

Čtrnáctová, H., Č́žžková, V., Ganajová, M., \& Šmejkal, P. (2011). Implementing inquiry science education in science teaching in the ESTABLISH project. Scientific papers University of Latia Science and Technology Education: Trends and main tendencies in the 21st century - 8th IOSTE Symposium of Central and Eastern Europe (pages 65-71). Riga: University of Latvia.

Čtrnáctová, H., Čížková, V., Hlavová, L., \& Řezníčková, D. (2012). Science Knowledge of Students in the Time of Curricular Reform (Monography). Krakow: Pedagogical University.

Čtrnáctová, H., Čížková, V., Marvánová, H., \& Pisková, D. (2007). Přírodovědné předměty v kontextu kurikulárních dokumentu a jejich hodnocení. Praha: Univerzita Karlova. ('Science subjects in the context of curricular documents and their evaluation')

ESTABLISH. (2010). Guide for developing Teaching and Learning Units. Amsterdam: AMSTEL Institute.

European Commision. (2007). Science Education Now: A renewed Pedagogy for the Future of Europe. Acquired 10. 06. 2012, from European Commission: ec.europa.eu/ research/sciencesociety/document_library/pdf_o6/report-rocard-on-science education_en.pdf

Franklin, W. A. (2000). Inquiry Based Approached to Science Education: Theory and Practice. Acquired 08. 06 2012, from www.brynmawr.edu/biology/franklin/ InquiryBasedScience.html

Mandíková, D., Houfková, J. (2012). Úlohy pro rozvoj př́rodovědné gramotnosti - Utváření kompetencí žáků na základě zjištění šetření PISA 2009. Praha: Česká školní inspekce. ('Tasks for the development of scientific literacy - Forming pupils' competences based on the findings of the PISA 2009 questionnaire')

MŠMT. (2009). MŠMT Akademické centrum studentských aktivit: Studie zahraničních zkušeností s podporou zájmu o technické a př́rodovědné obory. Praha: MŠMT. ('A study of foreign experience with the support of the interest for technical and scientific disciplines')

Pellegrino J. W., Histon M. L. (2012). Education for life and work: developing transferable knowledge and skills in the 21st century. National Academies Press, Washington 2012.

Řezníčková, D., Cídlová, H., Čížková, V., Čtrnáctová, H., Čudová, R., Hanus, M., Kubiatko, M., Marada, M., Matějček, T., Trnová, E. (2013). Dovednosti žáků ve výuce biologie, geografie a chemie. Praha: P3K s.r.o. ('Pupils' skills in the teaching of biology, geography and chemistry')

Sherborne, T. (2014). Enquiry \& TEMI CPD: Enquiry based science education \& continuing professional development (CPD). Acquired: 29. 05. 2015, from www.teachingmysteries.eu/wpcontent/uploads/2013/12/Enquiry-CPD.pdf 
IMPLEMENTING INNOVATIONS IN A

NON-FORMAL STUDENT LABORATORY CONTEXT

Sherwood, K. (2007). Effect of a problem based simulation on the conceptual understanding of undergraduate science education students. Journal of Science Education and Technology.

TEMI team. (2015). Teaching the TEMI way: How using mysteries supports science learning. London: Queen Mary University. 